\title{
PENERAPAN PENGELOLAAN TANAMAN TERPADU (PTT) PADI SAWAH BERAS MERAH DI DESA NYURLEMBANG KECAMATAN NARMADA LOMBOK BARAT
}

\author{
Ni Wayan Sri Suliartini ${ }^{* 1}$, I Gusti Putu Muliarta Aryana ${ }^{1)}$, AAK Sudharmawan'1), I \\ Wayan Sudika1), Dwi Ratna Anugrawati ${ }^{1)}$ \\ 1) Program Studi Agroekoteknologi Universitas Mataram \\ Jalan Majapahit Nomor 62, Kota Mataram Nusa Tenggara Barat \\ *alamat korespondensi: sri.suliartini@gmail.com
}

\begin{abstract}
ABSTRAK
Pengelolaan pertanian di kawasan Desa Nyurlembang Kecamatan Narmada masih belum berjalan optimal. Berbagai komponen dalam pengelolaan tanaman terpadu padi sawah seperti jajar legowo 4:1, umur bibit di atas 21 hari, dan mutu benih yang rendah, masih belum diterapkan sehingga menyebabkan produksi padi yang dihasilkan berkisar 4,5 ton -5 ton gabah kering panen. Penerapan pengelolaan tanaman terpadu padi sawah mampu meningkatkan produksi menjadi 6,9 ton gabah per hektar. Tujuan dari kegiatan Pengabdian Kepada Masyarakat adalah : Menambah pengetahuan petani dalam penerapan pengelolaan tanaman terpadu padi sawah beras merah, dan melaksanakan Demplot Pengelolaan Tanaman Terpadu budidaya padi sawah beras merah sehingga terjadi peningkatan produksi. Metode yang digunakan adalah metode ceramah, diskusi melalui penyuluhan dan demontrasi plot (demplot).Kegiatan pengabdian kepada masyarakat dilaksanakan di dDesa Nyurlembang Kecamatan Narmada Kabupaten Lombok Barat. Sasaran kegiatan ini adalah Kelompok Tani (Gapoktan) Subur Makmur yang berada di Desa Nyurlembang Kecamatan Narmada Lobar. Hasil penyuluhan dan demplot adalah Kelompok Tani Subur Makmur Desa Nyurlembang Kecamatan Narmada Kabupaten Lombok Barat telah memahami makna penerapan pengelolaan tanaman terpadu padi sawah beras merah terutama penggunaan tanam sistem jajar legowo 4:1, manfaat penggunaan benih bermutu, kelemahan penggunaan bibit tua ( $>21$ hari setelah semai) serta manfaat padi beras merah sebagai pangan fungsional. Melalui kegiatan pengabdian kepada masyarakat ini dihasilkan produksi padi galur harapan beras merah lebih tinggi dibandingkan dengan sistem tegel.
\end{abstract}

Kata kunci: padi sawah beras merah, benih bermutu, jajar legowo, Desa Nyurlembang 


\section{PENDAHULUAN}

Kabupaten Lombok Barat Propinsi Nusa Tenggara Barat (NTB) memiliki luas wilayah $1.053 .92 \mathrm{~km} 2$ yang terbagi dalam sepuluh wilayah kecamatan dengan 3 kelurahan dan 119 desa serta 796 jumlah dusun. Penggunaan lahan di kabupaten ini berdasarkan data dari Badan Pusat Statistik Kab. Lombok Barat (2012) adalah sawah seluas $16.903 \mathrm{Ha}$, bukan sawah 43.371 ha, lahan bukan pertanian 45.118 ha. Luasan lahan pertanian yang sangat luas dan kondisi tanah yang subur menyebabkan sebagaian besar penduduknya mengandalkan pertanian sebagai sumber penghasilan utamanya. Areal persawahan kabupaten ini cukup luas sehingga kabupaten ini merupakan salah satu lumbung beras Propinsi Nusa Tenggara Barat (BPS Kab. Lombok Barat, 2012).

Kecamatan Narmada sebagai lokasi kegiatan Pengabdian bagi Masyarakat memiliki luas wilayah terluas kedua setelah Kecamatan Sekotong, yaitu $50,23 \%$ dari luas Kabupaten Lombok Barat. Dari luasan ini sebagian besar lahannya masih dipergunakan sebagai lahan pertanian. Lahan pertanian tersebut berupa lahan sawah irigasi dengan luas 2.242 ha, terluas setelah Kecamatan Sekotong (3.040 ha). Ketinggian lokasi Kecamatan
Narmada berkisar dari $10 \mathrm{~m} \mathrm{dpl}$ hingga $100 \mathrm{~m}$ dpl dengan suhu udara berkisar antara 25,210C-32,780C. Kecamatan Narmada merupakan lumbung beras dari Kabupaten Lombok Barat dengan rata-rata produksi 5,417 ton ha-1 (BPS, 2012) Pelaksanaan pengabdian melibatkan satu kelompok tani yang berada pada Desa Nyurlembang Kecamatan Narmada Kabupaten Lombok Barat, memiliki jumlah anggota kelompok sebanyak 53 orang dengan luasan lahan garapan berupa sawah irigasi teknis seluas 47 ha. Kelompok tani ini pada umumnya sepanjang tahun menanam padi, sebagian kecil menanam palawija seperti kacang tanah, jagung, kedelai, kacang ijo maupun kacang panjang. Permasalahan yang dihadapi selama ini adalah perolehan produksi hasil panen tanaman padi umumnya menghasilkan gabah kering panen masih rendah yaitu sekitar 5,1 ton ha-1. Rendahnya hasil yang diperoleh pada kelompok tani ini adalah belum diterapkannya komponen paket teknologi secara utuh yaitu belum menggunakan sistim tanam jajar legowo 4:1, masih melakukan penanam dengan bibit umur tua dan tidak dilakukannya perlakuan benih dalam pelaksanaan budidayanya. Petani masih jarang menggunakan varietas unggul baru, mereka menggunakan varietas 
sebelumnya secara terus menurus dan tanpa adanya pergiliran dengan varietas lain seperti beras merah, serta penggunaan benih yang kurang bermutu.

Sistem jajar legowo adalah penataan tanaman padi dengan mengatur jarak tanam sedemikian rupa sehingga populasi meningkat dan jumlah tanaman yang mendapatkan efek pinggir lebih banyak dibandingkan dengan cara tanam biasa. Penerapan sistem tanam legowo menggunakan jarak tanam $(25 \times 25) \mathrm{cm}$ antar rumpun dalam baris; $12,5 \mathrm{~cm}$ jarak dalam baris; dan $50 \mathrm{~cm}$ sebagai jarak antar barisan/lorong atau ditulis $(25 \times 12,5 \times 50) \mathrm{cm}$. Dengan pola ini, populasi tanaman mencapai 256.000 rumpun ha-1 dengan peningkatan populasi sebesar $60 \%$ dibanding pola tegel $(25 \times 25) \mathrm{cm}$.

Menurut Sembiring (2001), sistem tanam legowo memiliki keuntungan sebagai berikut: terdapat ruang terbuka yang lebih lebar diantara dua kelompok barisan tanaman yang akan memperbanyak cahaya matahari masuk ke setiap rumpun tanaman padi, sehingga meningkatkan aktivitas fotosintesis yang berdampak pada peningkatan produktivitas tanaman. Sistem tanaman berbaris ini memberi kemudahan petani dalam pengelolaan usahataninya seperti: pemupukan susulan, penyiangan, pelaksanaan pengendalian hama dan penyakit (penyemprotan). Disamping itu, pengendalikan hama tikus menjadi lebih mudah, meningkatkan jumlah tanaman pada kedua bagian pinggir untuk setiap set legowo, sehingga berpeluang untuk meningkatkan produktivitas tanaman akibat peningkatan populasi. Sistem tanam jajar legowo ini mampu meningkatkan produktivitas padi hingga mencapai $10-20 \%$.

Penanaman bibit umur muda hingga dewasa (15-20 hari) memungkinkan tanaman untuk tumbuh lebih baik dengan jumlah anakan cenderung lebih banyak. Hal ini dikarenakan kemampun beradaptasi dan lebih cepat pulih dari stress akibat dipindahkan dari persemaian ke lahan pertanaman .

Peranan penggunaan varietas unggul baru sangat besar dalam peningkatan produksi nasional. Salah satu faktor utama yang menghambat kelancaran adaptasi VUB adalah kurangnya pengujian dan demplot sehingga petani cendrung mempertahankan varietas yang lama dan telah pupuler seperti Ciherang dan IR64. Kedua varietas ini semakin lama mulai menurun ketahanannya terhadap hama dan penyakit sehingga lambat laun jika dilakukan penanaman terus menerus dengan varietas yang sama, suatu ketika dapat terjadi gagal panen. Solusi yang perlu dilakukan pergiliran 
varietas, salah satunya penggunaan padi beras merah fungsional (Suliartini et al., 2011; 2015; 2016).

Padi beras merah (Oryza sativa) merupakan bahan pangan pokok fungsional selain bernilai kesehatan tinggi juga sebagai pewarna alami untuk industri pangan. Alueron dan endosperm padi beras merah memproduksi antosianin tinggi. Antosianin adalah senyawa fenolik yang masuk kelompok flavonoid dan berfungsi sebagai antioksidan, berperan penting baik bagi tanaman itu sendiri maupun bagi kesehatan manusia. Analisis laboratorium menunjukkan bahwa beras merah mengandung protein $\quad(5,51 \%)$, lemak $(1,85 \%)$, amilosa $(22,97 \%)$, amilopektin $(51,54$ $\%)$, dan pati (14,52 \%). Beras merah juga mengandung beta-karotin $804,16 \mathrm{mg} / 100$ gram dan antosianin 393,93 ppm. Kandungan pati dan amilosa yang rendah mengakibatkan nasi pulen, oleh karena itu harga beras merah lebih mahal jika dibandingkan dengan harga beras putih. Saat ini kebutuhan akan beras merah terus meningkat sejalan dengan kesadaran masyarakat tentang manfaat kesehatan (Abdel et al., 2006; Harmanto, 2008; Kristaminanti dan Purwaningsih, 2010; Kristaminanti et al., 2012).

Bertolak dari pemikiran tersebut di atas dan dalam rangka ikut berperan aktif serta membantu program pemerintah di bidang pertanian, dirasakan sangat perlu dilakukan penerapan paket teknologi budididaya padi sawah beras merah, melalui penyuluhan penerapan PTT serta demontrasi plot.

\section{METODE KEGIATAN}

Observasi awal di Desa
Nyurlembang Kec. Narmada
menunjukkan masih rendahnya
tingkat penerapan pengelolaan
tanaman terpadu (PTT) padi sawah.
Petani masih banyak yang belum
menerapkan PTT padi sawah secara
utuh. Sebagai akibatnya, produksi
padi sawah belum mencapai produksi
yang optimal. Hal ini disebabkan
petani masih kurang yakin terhadap
pelaksanaan PTT mampu
meningkatkan produksi padi sawah.
Perlu ada penyuluhan yang mampu
meningkatkan pemahaman dan
pengetahuan petani tentang PTT
budidaya padi sawah, disertai
demonstrasi plot yang dapat
menunjukkan pada petani tentang
manfaat penerapan PTT budidaya
padi sawah secara utuh dan
menyaksikan hasil di lapangan
dengan peran serta petani secara
langsung. Kegiatan pengabdian kepada
masyarakat dilaksanakan di Desa
Nyurlembang Kecamatan Narmada
Kabupaten Lombok Barat. Metode
yang digunakan adalah metode
androgogi dengan menekankan


partisipasi aktif dari kelompok tani dan demontrasi lapang (demplot).

Pelatihan secara klasikal dilaksanakan selama satu hari melalui metode penyuluhan dengan ceramah dan diskusi. Pendampingan teknis berupa demplot dilaksanakan selama 4 bulan pada luasan lahan 10 are. Jumlah peserta pelatihan 25 peserta yang terdiri atas anggota kelompok tani Subur Makmur dari Desa Nyurlembang Kecamatan Narmada Kabupaten Lombok Barat.

Materi kegiatan pelatihan dan pendampingan meliputi teknologi budidaya padi sawah beras merah tentang sistem tanam jajar legowo, penggunaan benih unggul dan penggunaan umur bibit tidak terlalu tua, serta manfaat padi beras merah bagi kesehatan.

\section{HASIL DAN PEMBAHASAN}

Kegiatan 1 (pertama) berupa penyuluhan telah dilaksanakan di Kebun Percobaan Fakultas Pertanian Universitas Mataram Kecamatan Narmada Kabupaten Lombok Barat yang dihadiri oleh 26 anggota kelompok tani Subur Makmur (Gambar 1). Kegiatan pelatihan ini diawali dengan acara pembukaan, kemudian dilanjutkan penyampaian materi penyuluhan.

Perbedaan antara beras merah dan putih serta manfaatnya bagi kesehatan serta penerapan PTT budidaya padi sawah beras merah yang meliputi persiapan benih unggul, persiapan lahan (pengolahan tanah), persemaian, penanaman dan pemeliharaan yang meliputi pemupukan, pengaturan pengairan, penyulaman, pengendalian gulma kemudian, panen, perontokan dan pengolahan. Setelah dilakukan penyampaian materi penyuluhan, kegiatan dilanjutkan dengan acara diskusi. Respon petani sangat bagus, tercermin dari banyaknya pertanyaan yang diajukan seperti mulai dari manfaat lain dari padi beras merah, perbedaan kandungan padi beras merah dan putih, sistem tanam jajar legowo yang paling menguntungkan serta keinginan untuk dilaksanakanya demplot.

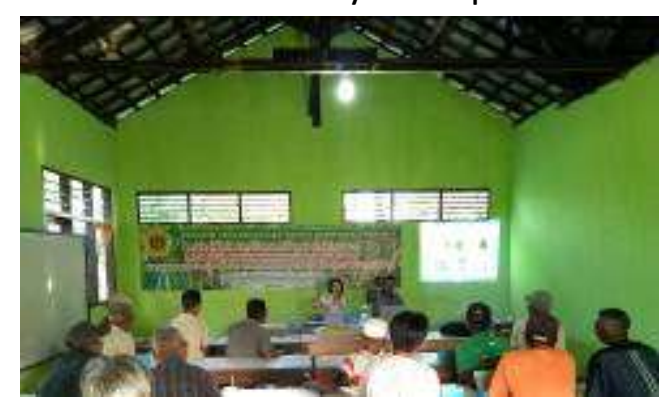

Gambar 1. Tim penyuluh menyampai materi tentang Penerapan PTT budidaya padi sawah beras merah

Rangkuman dari pertanyaan yang diajukan dapat diuraikan sebagai berikut : Adapun manfaat lain dari padi beras merah selain merupakan bahan pangan pokok yang mengandung karbohidrat, lemak, protein, serat dan mineral, beras merah juga mengandung 
antosianin. Antosianin merupakan pigmen merah yang berfungsi sebagai antioksidan, berperan penting bagi kesehatan seperti mencegah penyakit hati (hepatitis), kanker usus, stroke, diabetes, sangat esensial bagi fungsi otak dan mengurangi pengaruh penuaan otak (Herani dan Rahardjo, 2005). Harga beras merah lebih mahal dari pada harga beras putih. Harga dapat mencapai Rp. 26.000 per kg.

Untuk perbedaan kandungan gizi antara padi beras merah dan putih dapat dijelaskan sebagai berikut: terhadap komposisi gizi per 100 gram padi beras merah dibandingkan dengan beras putih disajikan dalam Tabel 1.

Tabel 1. Kandungan gizi antara beras putih dan merah

\begin{tabular}{llll}
\hline No & $\begin{array}{l}\text { Kandungan } \\
\text { gizi }\end{array}$ & $\begin{array}{l}\text { Beras } \\
\text { putih }\end{array}$ & $\begin{array}{l}\text { Beras } \\
\text { merah }\end{array}$ \\
\hline 1 & Energy & $357 \mathrm{Kkal}$ & $351 \mathrm{Kkal}$ \\
2 & Protein & $8.4 \mathrm{~g}$ & $8 \mathrm{~g}$ \\
3 & Lemak & $1.7 \mathrm{~g}$ & $1.3 \mathrm{~g}$ \\
4 & Karbohidrat & $77.1 \mathrm{~g}$ & $76.9 \mathrm{~g}$ \\
5 & Serat & $0.2 \mathrm{~g}$ & $20.1 \mathrm{~g}$ \\
\hline
\end{tabular}

Dari hasil penelitian yang dilakukan oleh Ok et al. (2001) cit. Narwidina (2009), beras merah mempunyai kandungan serat pangan (dietary fiber) dan hemiselulosa masing-masing sebesar 7,5\% dan $5,8 \%$, sedangkan beras putih hanya sebesar $5,4 \%$ dan $2,2 \%$

Pertanyaan tentang perlakuan benih apa yang harus diberikan untuk memperbaiki pertumbuhan dan meningkatkan hasil panen padi dapat dijelaskan. Hama tanaman padi dapat terbawa benih dan akan ada di lapangan setelah benih ditanam. Keberadaan hama pada benih dan tanaman padi akan mengurangi hasil sehingga produksi dan pendapatan petani menurun. Perendaman benih dengan cruiser dilakukan setelah benih direndam dengan air selama 12 jam. Perendaman dengan cruiser 350FS $12,5 \mathrm{ml}$ dilakukan selama 10 menit

Cruiser merupakan insektisida perlakuan benih yang sistemik, diserap lewat akar dengan sempurna dan ditranslokasikan ke semua bagian tanaman, termasuk titik tumbuh. Bahan aktif yang ada di dalam Cruiser 350 FS sangat efektif untuk mengendalikan hama penusukpenghisap seperti wereng, kutu daun, kepik, dan kumbang pemakan daun melalui perlindungan dini pada benih. Insektisida ini sangat mudah diaplikasikan, lebih mudah larut dalam air, mudah meresap dan perlindungan pada benih lebih merata.

Cruiser 350 FS dapat digunakan untuk perlakuan benih maupun bibit, serta untuk disemprotkan pada tanaman muda di lapangan. Penggunaan Cruiser 350 FS pada padi sawah secaea nyata akan memperlihatkan tanaman tampak lebih cepat tumbuh, perakaran 
tanaman lebih panjang, meningkatkan tinggi tanaman, jumlah anakan, bobot 1000 butir, jumlag anakan produktif serta hasil panen.

Atonik adalah zat pengatur tumbuh (ZPT) tanaman berbentuk cairan yang dapat meningkatkan produktivitas dan ketahanan tanaman terhadap serangan penyakit. Cara aplikasinya adalah campurkan 0.5-1 $\mathrm{ml}$ atonik ke dalam $1 \mathrm{~L}$ air. Manfaat atonik adalah (1), Mempercepat pertumbuhan tanama karena unsur hara terserap lebih baik, (2) Mempercepat perbaikan tanaman yang rusak akibat hama, (3) Meningkatkan produktivitas tanaman, (4) Meningkatkan daya tahan tanaman agar lebih tahan terhadap serangan hama dan penyakit, (5) Mempercepat perkecambahan pada benih tanaman dengan cara merendam benih dalam larutan atonik selama 1jam sebelum disemai.

Pertanyaan apa yang dimaksud dengan sistem jajar legowo, jajar legowo 4:1 serta jarak tanam yang optimum dapat dijelaskan. Sistem jajar legowo adalah penataan tanaman padi dengan mengatur jarak tanam sedemikian rupa sehingga populasi meningkat dan jumlah tanaman yang mendapatkan efek pinggir lebih banyak dibandingkan dengan cara tanam biasa. Tanaman yang seharusnya berada pada baris disisipkan pada baris pinggir sehingga satu baris menjadi lorong.

Jajar legowo $4: 1$ adalah setiap empat baris tanaman padi diselingi dengan satu baris kosong dengan lebar dua kali jarak tanam, dan untuk Jarak tanam tanaman padi yang dipinggir menjadi setengah jarak tanam dalam barisannya. Penerapan sistem tanam legowo menggunakan jarak tanam $(25 \times 25) \mathrm{cm}$ antar rumpun dalam baris; $12,5 \mathrm{~cm}$ jarak dalam baris; dan $50 \mathrm{~cm}$ sebagai jarak antar barisan/ lorong atau ditulis $(25 \times 12,5 \times 50) \mathrm{cm}$.

Sistem tanam legowo 4:1 tipe 1 merupakan pola tanam legowo dengan keseluruhan baris mendapat tanaman sisipan. Pola ini cocok diterapkan pada kondisi lahan yang kurang subur. Dengan pola ini, populasi tanaman mencapai 256.000 rumpun/ha dengan peningkatan populasi sebesar $60 \%$ dibanding pola tegel $(25 \times 25) \mathrm{cm}$.

Menurut Sembiring (2001), sistem tanam legowo merupakan salah satu komponen PTT pada padi sawah yang apabila dibandingkan dengan sistem tanam lainnya memiliki keuntungan sebagai berikut: Terdapat ruang terbuka yang lebih lebar diantara dua kelompok barisan tanaman yang akan memperbanyak cahaya matahari masuk ke setiap rumpun tanaman padi, sehingga meningkatkan aktivitas fotosintesis 
yang berdampak pada peningkatan produktivitas tanaman. Sistem tanaman berbaris ini memberi kemudahan petani dalam pengelolaan usahataninya seperti: pemupukan susulan, penyiangan, pelaksanaan pengendalian hama dan penyakit (penyemprotan). Disamping itu, pengendalian hama tikus menjadi lebih mudah, meningkatkan jumlah tanaman pada kedua bagian pinggir untuk setiap set legowo, sehingga berpeluang untuk meningkatkan produktivitas tanaman akibat peningkatan populasi. Sistem tanaman berbaris ini juga berpeluang bagi pengembangan sistem produksi padi-ikan (mina padi) atau parlebek (kombinasi padi, ikan, dan bebek). Dengan system tanam jajar legowo ini mampu meningkatkan produktivitas padi hingga mencapai 10-20 \%. Kelemahan tanam jajar legowo adalah akan membutuhkan tenaga kerja yang lebih banyak dan waktu yang lebih lama pada saat melakukan proses penanaman padi, membutuhkan benih yang lebih banyak, dikarenakan semakin banyaknya populasi tanaman padi, pada umumnya pada lahan yang menggunakan jajar legowo akan ditumbuhi rumput lebih banyak.

Kaitannya dengan pertanyaan dari peserta penyuluhan tentang keuntungan penanaman bibit yang tidak terlalu tua adalah : Penanaman bibit umur muda (15-20 hari) memungkinkan tanaman untuk tumbuh lebih baik dengan jumlah anakan cendrung lebih banyak. Kemampun beradaptasi dan lebih cepat pulih dari stress akibat dipindahkan dari persemaian ke lahan pertanaman, serta umur berbunga lebih awal.

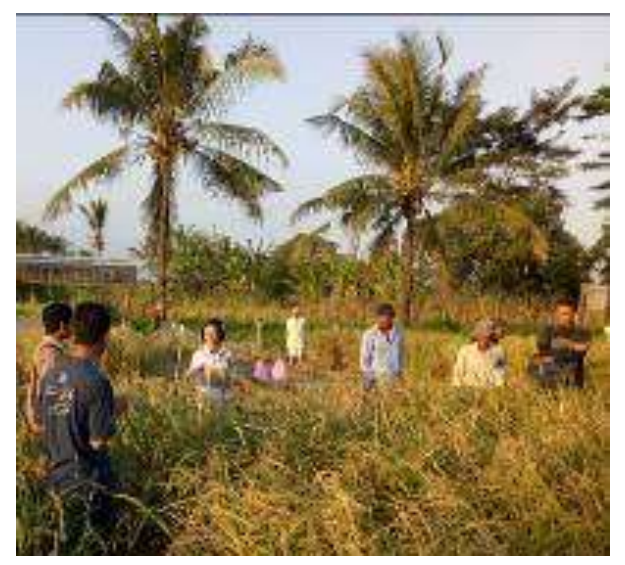

Gambar 2. Penjelasan tentang ciri ciri penampilan tanaman padi beras merah

Kegiatan 2 berupa Demplot “ Budidaya padi sawah beras merah". Kegiatan ini dilakukan dengan menggunakan tanaman galur harapan padi beras merah hasil seleksi bulk yang berasal dari pemulia Prof I Gusti Putu Muliarta Aryana Fakultas Pertanian Universitas Mataram. Kegiatan demplot dilaksanakan di kebun percobaan Fakultas Pertanian Unram dimulai Juni - Oktober 2019 yang dikoordinir oleh ketua kelompok taninya. Kegiatan ini diawali dengan melakukan persemaian. Persemaian dibuat 20 hari sebelum tanam 
dengan luas $5 \%$ dari luas petakan yang akan ditanami padi. Tanah persemaian dicangkul kemudian digaru, lalu dibuat bedengan dengan lebar 1,25 $\mathrm{m}$ dan panjangnya disesuaikan dengan panjang petak.

Benih padi yang sudah terpilih direndam selama 24 jam, air rendaman diganti setelah 12 jam dengan air baru. Benih direndam kembali dengan atonik dan cruiser, masing-masing selama 10 menit. Setelah direndam benih diperam dengan karung goni selama 48 jam ditempat teduh.

Setelah diperam, air dalam petak persemaian dikurangi hingga permukaan tanah bebas dari genangan air, kemudian bedengan dipupuk dengan pupuk Ponska dosis $10 \mathrm{gram} / \mathrm{m} 2$, kemudian benih ditaburkan dengan ukuran 2 genggam/m2, selanjutnya benih dibenamkan kedalam lumpur.

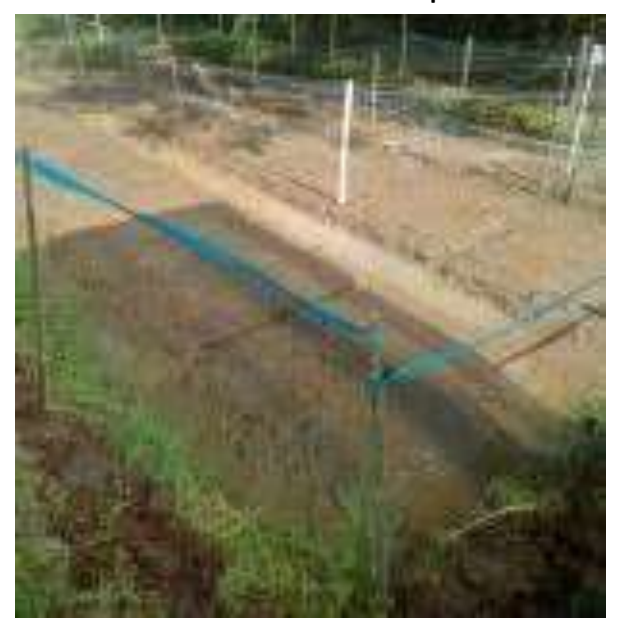

Gambar 3. Persiapan persemaian, bedeng persemaian ditaburi pupuk dasar Ponsca $10 \mathrm{~g} / \mathrm{m}^{2}$ dan Furadan 5 $\mathrm{g} / \mathrm{m}^{2}$
Hari 1-5 permukaan air dipertahankan sedikit di bawah permukaan bedengan, umur 10 hari dipupuk dengan pupuk urea dengan dosis $10 \mathrm{gram} / \mathrm{m} 2$, pengaturan air persemaian selanjutnya adalah dengan mengatur tinggi air dengan mengikuti tinggi bibit. Pada umur 20 hari bibit siap dipindah tanam. Sebelum dicabut petakan digenangi air terlebih dahulu untuk menghindari kerusakan akar pada saat pencabutan bibit.

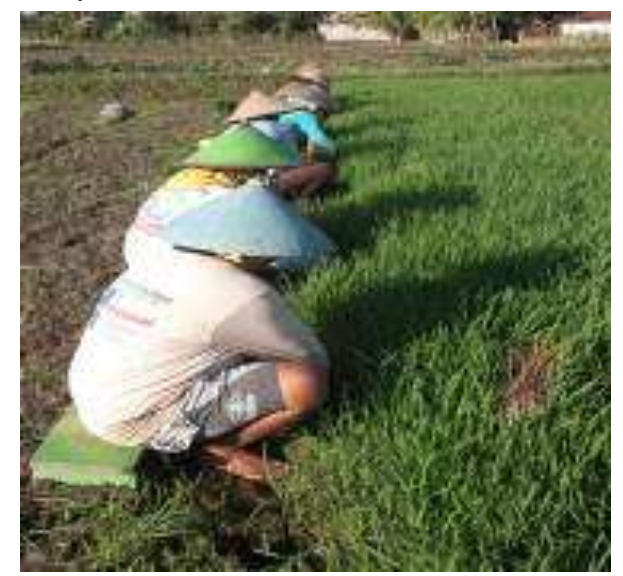

Gambar 4. Pencabutan bibit tanaman umur 19 hari.

Sebelum dilakukan penanaman lahan diolah. Kegiatan pengolahan tanah dilakukan dengan langkah langkah : satu minggu sebelum pengolahan tanah, petak sawah diberi air sampai cukup untuk melunakan tanah, kemudian petak sawah dibajak, setelah dibajak petakan digenangi sedalam $10 \mathrm{~cm}$ selama 7 hari, kemudian dilakukan penggaruan I, setelah dilakukan penggaruan, air dipertahankan selama 7 hari, kemudian dilanjutkan dengan penggaruan II. 
Sebelum ditanam petakan dibuat larikan dengan caplak ukuran $25 \times 25 \mathrm{~cm}$. Ukuran petak seluas 10 are. Petak ini berfungsi sebagai petak demplot.

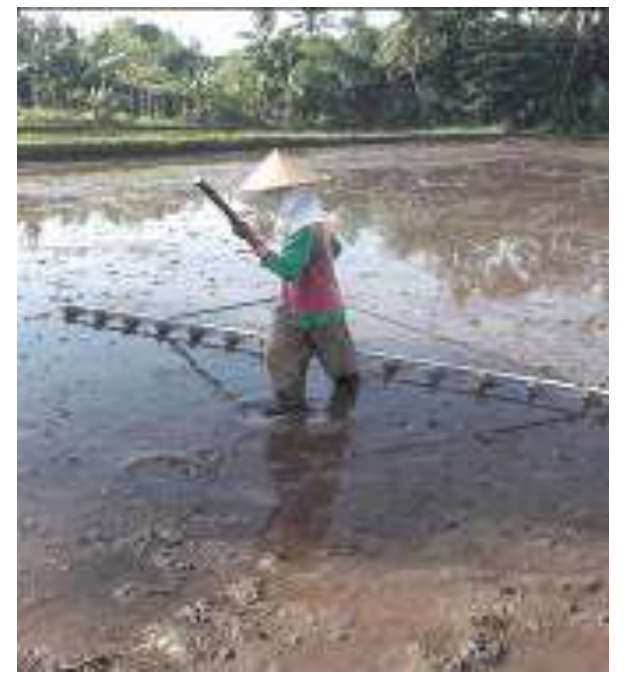

Gambar 5. Caplak dengan ukuran 25 $\mathrm{cm} \times 25 \mathrm{~cm}$

Penaman dilakukan dengan system jajar legowo 4:1 dengan jumlah bibit 1 bibit/lubang dengan jarak tanam $25 \times 25 \mathrm{~cm}$. Untuk mencegah serangan dari ulat penggulung serta batang muda (hama sundep) maka dilakukan pengendalian dengan insektisida prevaton pada umur 10 hss (Gambar.6).

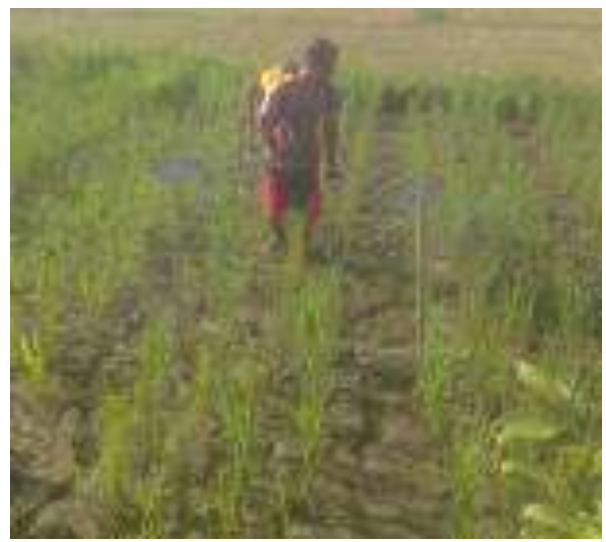

Gambar 6. Pengendalian hama penggulung daun pada tanaman beras merah

Pemupukan pertanaman dengan dosis $300 \mathrm{~kg}$ Ponska/ha dan 200 Urea kg/ha. Diaplikasi 3 kali pupuk dasar $300 \mathrm{~kg}$ Poska/ha 1 minggu setelah tanam (7 hari hss) (Gambar 7) . Pupuk susulan $100 \mathrm{~kg}$ Urea /ha umur 30 hst dan $100 \mathrm{~kg}$ Urea/ha umur 50 hst.

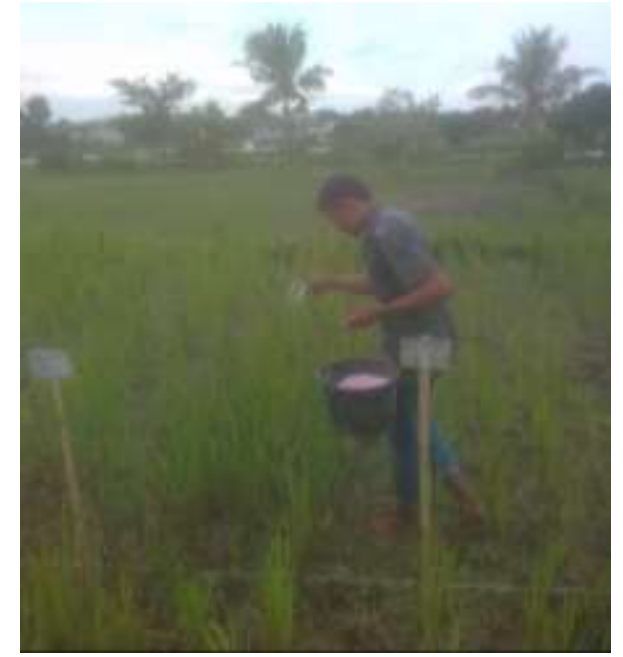

Gambar 7. Pemupukan dasar dengan Ponska dosis $300 \mathrm{~kg} / \mathrm{ha}$ serta penggunaan herbisida ally plus pada umur tanaman padi umur 7 hss dan penggunaan Urea 100 $\mathrm{kg} / \mathrm{ha}$ pada umur 30 hss

Pengaturan pengairan : yang perlu diperhatikan adalah penanaman bibit dilaksanakan pada kondisi lahan sawah sudah jenuh air atau air macak-macak. Kedalaman air 2-3 cm harus dijaga selama 7-10 hari setelah tanam. Penggenangan air setinggi $5 \mathrm{~cm}$ sangat penting pada fase vegetatif. Dari fase keluarnya malai sampai pengisian biji penggenangan air harus cukup. Dari 
pengisian biji sampai 7 hari sebelum panen, cukup diberi pengairan secara berselang. Pindahkan bibit pada umur $<21$ hari dan tanam secara dangkal (bibit padi hibrida Jepang pada umur bibit 14 hari). Pemindahan bibit yang lebih tua akan menghambat fase pembungaan. Pemindahan bibit muda mempercepat fase pembungaan.

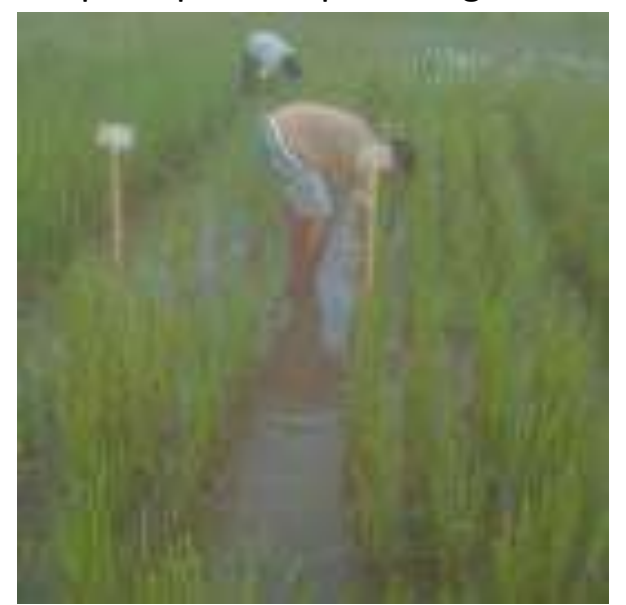

Gambar 8. Penyiangan secara mekanik dengan mencabut gulma yang tumbuh

Penyulaman dilakukan dengan menggunakan bibit yang tersisa di persemaian dengan jangka waktu penyulaman seminggu setelah tanam. Hal ini diperlukan untuk menjaga diperolehnya populasi optimum pada tanaman padi. Pelihara lahan pertanaman agar bebas dari gulma dengan menyiangi rumput dengan tangan atau menggunakan herbisida diikuti penyiangan berputar (dengan sosrok). Pengendalian gulma terpadu dengan cara pemberian herbisida 5-7 hari setelah tanam diikuti dengan penyiangan rumput dengan sosrok diantara barisan tanaman pada umur 21 hari setelah tanam dapat memberi hasil yang lebih baik. Herbisida purna tumbuh dupont ally plus 77WP ini efektif memberantas gulma pengganggu tanaman padi. Aplikasinya dapat disemprot maupun dicampur dengan pupuk, ini memungkinkan petani untuk menghemat waktu pemeliharaan. Pencampuran pupuk dilakukan dengan bertahap, apabila tersedia 6 kg pupuk urea untuk ditabur di areal sawah seluas 35 meter persegi, Sebagai alternatif penyiangan menggunakan tangan dapat dilakukan pada umur 21 dan 35 hari setelah tanam apabila diperlukan.

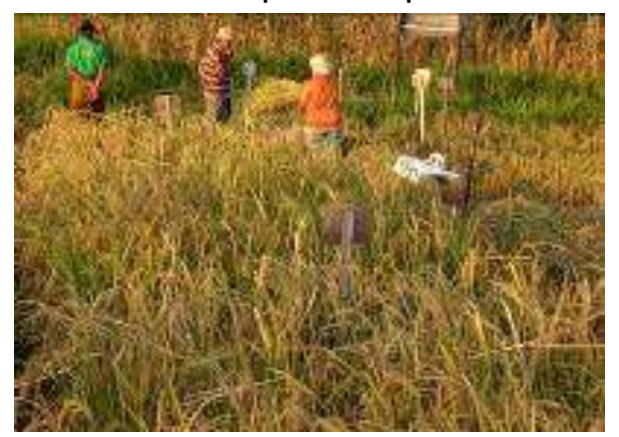

Gambar 9. Panen dan rampek

Panen, Perontokan dan

Pengolahan. Panen dilakukan setelah daun menguning, lebih dari $80 \%$ gabah menguning dan mengeras (Gambar 9). Pemanen dilakukan dengan sistem Rampek (tangan). Kemudian dijemur di lantai jemur yang beralaskan semen hingga kadar air benih berkisar antara 13-14\%. Setelah pengeringan, benih dapat dikemas pada karung goni atau 
kantong kain. Partisipasi kelompok tani Nyurlembang pada tahapan kegiatan-kegiatan budidaya demplot cukup baik mulai dari pengolahan, pembibitan hingga panen. Partisipasi paling menonjol yaitu pada saat proses menjelang panen, karena tahapan ini para petani dapat melihat penampilan tinggi tanaman, bentuk daun bendera, bentuk malai, kebernasan malai, gabah dan warna beras merah. Berdasarkan penampilan galur harapan padi beras merah (Gambar 10), beberapa petani berkeinginan untuk melakukan penanaman padi beras merah pada lahannya.

Gambar 10. Penampilan warna beras merah

\section{KESIMPULAN DAN SARAN}

\section{Kesimpulan}

1. Kelompok Tani Subur Makmur Desa Nyurlembang Kecamatan Narmada Kabupaten Lombok Barat telah memahami makna penerapan pengelolaan tanaman terpadu budidaya padi sawah beras merah terutama penggunaan tanam sistem jajar legowo 4:1, manfaat penggunaan benih bermutu, kelemanan penggunaan bibit tua serta manfaat padi merah serta perbedaan komposisi kandungan gizi antara padi merah dan putih.

2. Melalui hasil demplot penerapan pengelolaan tanaman terpadu budidaya padi beras merah dengan sistem jajar legowo 4:1, pengunaan benih bermutu dan umur bibit optimum dihasilkan produksi hasil padi galur harapan padi beras merah lebih tinggi dibandingkan dengan system tegel.

\section{Saran}

Dari hasil kegiatan pengabdian kepada masyarakat ini diharapkan agar para anggota kelompok tani Subur Makmur mau mencoba untuk menanam padi beras merah untuk kebutuhan pangan khususnya untuk kesehatan.

\section{UCAPAN TERIMA KASIH}

\begin{tabular}{lrr}
\multicolumn{1}{c}{ Ucapan terima kasih di } \\
sampaikan & kepada & Fakultas \\
Pertanian & Universitas Mataram yang \\
telam membiayai & program \\
Pengabdian Kepada & Masyarakat \\
Sumber Dana PNBP 2019.
\end{tabular}




\section{DAFTAR PUSTAKA}

Abdel - Aal ESM, J. C. Young and I. Rabalski,2006. anthocyanin composition in Black, Pink, purple, and red cereal grains. J . Agric. Food Chem. 54, 469 4704.

Badan Pusat Statistik Kabupaten Lombok Barat, 2012. Lombok Barat Dalam Angka. Kerjasama Bappeda Kabupaten Lombok Barat BPS Kabupaten Lombok Barat. $350 \mathrm{~h}$.

Harmanto, A. 2008. Varietas beras organic berdasarkan warna. http://aghribisnisgenesha.com.p.146. Download 26 September 2008.

Kristaminanti. 2012. Keragaan beras hitam sebagai sumberdaya genetik lokal. Makalah pada acara Aplikasi Paket Teknologi BPTP Yogyakarta.

Kristaminanti dan Purwaningsih. 2010. Kandungan Besi beras hitam dan beras hitam lokal Yogyakarta. Proseding Seminar Nasional Hasil Penelitian Padi 2009. Balai Besar Peneltian Tanaman Padi. Badan Peneltian dan Pengembanagan Pertanian Kementrian Pertanian.

Sembiring H. 2010. Ketersediaan inovasi teknologi unggulan dalam meningkatkan produksi padi menunjang swasembada dan ekspor. Buku I (1-16). Prosiding seminar nasional hasil penelitian padi 2009. Inovasi teknologi padi untuk mempertahankan swasembada dan mendorong ekspor beras. Balai Besar Penelitian Tanaman Padi. Badan Penelitian dan Pengembanagan Pertanian Kementerian Pertanian.

Suliartini NWS, Sadimantara GR, Wijayanto $T$ dan Muhidin. 2011. Pengujian antosianin padi gogo beras merah hasil koleksi plasma nutfah Sulawesi Tenggara. Crop Agro 4 (2): 4348.

Suliartini NWS, Kuswanto N, Basuki A. Soegianto. 2015. Peningkatan keragaman hasil dan sifat agronomis lain pada dua kultivar padi gogo beras merah lokal melalui induksi mutasi. Disertasi. Program Pascasarjana Faculty of Agricultural, Brawijaya University.

Suliartini NWS, Kuswanto N, Basuki A. Soegianto. 2016. Superior lines candidates evaluation of two local red rice Southeast Sulawesi cultivars (Indonesia) derived from gamma rays irradiation techniques. International Journal of Plant Biology 7(6475): 64-67 